
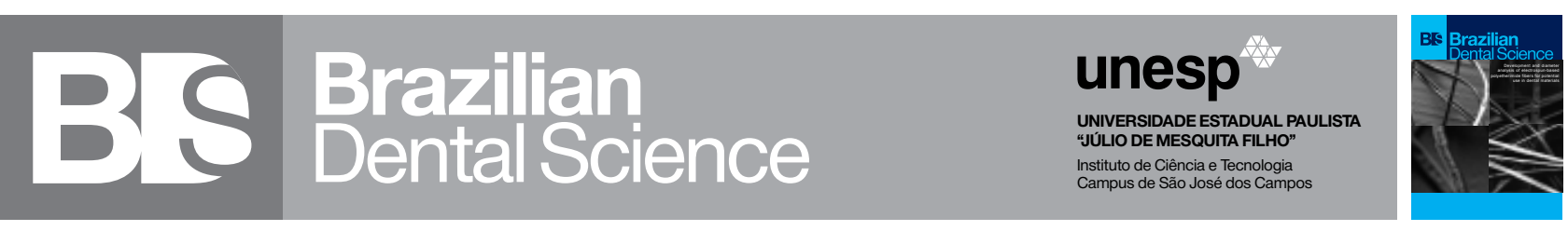

\title{
In-vitro efficacy of two spectrophotometer-based shade matching systems for color matching of ceramics after artificial accelerated aging
}

Eficácia in vitro de dois espectrofotômetros baseados em escalas de cor para avaliação de cor de cerâmicas após envelhecimento artificial acelerado

Fawaz ALQAHTANI ${ }^{1}$

1 - Department of Prosthodontics, College of Dentistry, Prince Sattam Bin Abdulaziz University, Al-Kharj 11942, Saudi-Arabia.

\section{ABSTRACT}

Objective: The objective of the present invitro study was to verify the efficacy of two spectrophotometer-based shade matching systems for color matching of ceramics after artificial accelerated aging (AAA). Material and Methods: The ceramics used were porcelain laminated veneers. Seventy standard-shaped discs (thickness $\mathrm{x}$ diameter: $0.5 \mathrm{~mm} \times 10 \mathrm{~mm}$ ) of $B 1$ shades were used. Based upon the type of resin cement used, the specimens were divided into seven groups (10/group). The following light-cured cements were used: RelyX-Veneer (L-RV), Variolink-Veneer (L-VV), and VariolinkEsthetic (L-VE). The dual-cured cements were: RelyX Ultimate (D-RU), RelyX-Unicem (D-RC), and Variolink-Esthetics DC (D-VE). The control group consisted of ceramic only. All specimens were thermocycled in water for 3,500 cycles between $5{ }^{\circ} \mathrm{C}-55{ }^{\circ} \mathrm{C}$, with dwell times of $30 \mathrm{~s}$ in each bath and a transfer time of $10 \mathrm{~s}$ between baths. All specimens were thermocycled in water for 3,500 cycles between $5{ }^{\circ} \mathrm{C}$ and $55^{\circ} \mathrm{C}$, and color measurement was done using the VITA Easyshade and ColorEye spectrophotometers. Baseline color reading was performed 24-hours after cementation. Differences in color (DE) of EasyShade and ColorEye before and after AAA were determined and compared statistically. Group comparisons were done using the paired t-tests. Level of significance was set at $\mathrm{P}<0.05$. Results: The mean differences in color $(\Delta \mathrm{E})$ values obtained from Easyshade

\section{RESUMO}

Objetivos: O objetivo do presente estudo in vitro foi verificar a eficácia de dois espectrofotômetros baseados em escalas de cor para avaliação de cor de cerâmicas após envelhecimento artificial acelerado (EAA). Material e Métodos: As cerâmicas utilizadas foram laminados cerâmicos. Foram usados setenta discos de formato padrão $(0,5 \mathrm{~mm}$ de espessura x $10 \mathrm{~mm}$ de diâmetro) de tonalidades B1. Com base no tipo de cimento resinoso utilizado, os corposde-prova foram divididos em sete grupos (10 / grupo). Foram utilizados os seguintes cimentos fotopolimerizáveis: RelyX-Veneer (L-RV), Variolink-Veneer (L-VV) e VariolinkEsthetic (L-VE). Os cimentos de cura dual foram: RelyX Ultimate (D-RU), RelyX-Unicem (D-RC) e Variolink-Esthetics DC (D-VE). O grupo controle consistia apenas de cerâmica. Todos os corpos-de-prova foram termociclados em água por 3.500 ciclos entre $50 \mathrm{oC}-55 \mathrm{oC}$, com tempos de permanência de 30 s em cada banho e um tempo de transferência de 10 s entre os banhos. A medição da cor foi feita usando os espectrofotômetros VITA Easyshade e ColorEye. A leitura da cor inicial foi realizada 24 horas após a cimentação. As diferenças na cor $(\Delta \mathrm{E})$ do EasyShade e ColorEye antes e depois do EAA foram determinadas e comparadas estatisticamente. As comparações dos grupos foram feitas usando $\mathrm{o}$ teste $\mathrm{t}$ pareados. O nível de significância foi estabelecido em $\mathrm{p}<0,05$. Resultados: os valores médios de diferenças na cor $(\Delta \mathrm{E})$ obtidos 
spectrophotometer for light- and dual-cured cements, were $0.843 \pm 0.89$ (L-RV ), $4.11 \pm 0.69$ (L-VV) and 0.833 \pm 0.47 (L-VE); and 2.22 \pm 0.64 (D-RU), 3.37 \pm 0.83 (D-RC) and 0.38 \pm 0.92 (D-VE), respectively. The mean differences in color $(\Delta \mathrm{E})$ values obtained from ColorEye spectrophotometer for light- and dual-cured cements, were $0.68 \pm 0.86$ (L-RV ), $4.55 \pm 0.83$ (L-VV) and 2.68 \pm 0.26 (L-VE); and 2.06 \pm 0.84 (D-RU), $1.8 \pm 1.08$ (D-RC) and 0.96 \pm 0.71 (DVE), respectively. There was no significant difference in the mean DE values among the groups. Conclusion: The VITA Easyshade and ColorEye shade matching systems are comparable in terms of their efficacy for color matching of cerammics after AAA.

\section{KEYWORDS}

Artificial accelerated aging; Color matching; In vitro; Porcelain veneer; Spectrophotometer. no espectrofotômetro EasyShade para cimentos fotopolimerizáveis e duais foram de 0,843 \pm 0,89 (L-RV), 4,11 $\pm 0,69$ (L-VV) e 0,833 $\pm 0,47$ (L-VE ); e 2,22 $\pm 0,64$ (D-RU), 3,37 $\pm 0,83$ (DRC) e 0,38 $\pm 0,92$ (D-VE), respectivamente. os valores médios de diferenças na cor $(\Delta \mathrm{E})$ obtidos no espectrofotômetro ColorEye para cimentos fotopolimerizáveis e duais foram de 0,68 \pm 0,86 $(\mathrm{L}-\mathrm{RV}), 4,55 \pm 0,83(\mathrm{~L}-\mathrm{VV})$ e $2,68 \pm 0,26$ (L$\mathrm{VE}$ ); e 2,06 \pm 0,84 (D-RU), 1,8 $\pm 1,08$ (D-RC) e $0,96 \pm 0,71$ (D-VE), respectivamente. Não houve diferença significativa nos valores médios de $\Delta \mathrm{E}$ entre os grupos. Conclusão: Os sistemas de combinação de cores VITA Easyshade e ColorEye são comparáveis em termos de eficácia para avaliação de cores de cerâmicas após EAA.

\section{PALAVRAS-CHAVE}

Envelhecimento artificial acelerado; Avaliação de cores; In vitro; Laminado cerâmico; Espectrofotômetro.

\section{INTRODUCTION}

\begin{abstract}
A cautious recreation of prosthetic restorations in relation to their texture, translucency, shape, and shade is essential to replicate the natural appearance of dentition [1]. It has been reported that most of the complications in restorative dental sciences are associated with discrepancies in color-matching procedures [2]. With the escalating mandate for esthetic dental restorations, the importance of consistent color imitation has intensified. In this context, appropriate selection and replication of that shade is considered a critical step towards the achievement of a color of the restoration that matches with the natural dentition. Accomplishment of such an outcome is dependent on the ability to determine the precise tooth shade in a precise yet consistent manner [1].
\end{abstract}

The VITA Easyshade V digital spectrophotometer (Vita Zahnfabrik GmbH \& Co. KG, Bad Säckingen, Germany) is often used for the determination of shade veneers that closely matches with that of the natural dentition [3]. However, prosthesis that are colormatched using conventional visual shade-guides are more often rejected than those matched using spectrophotometers [4]. In this context, spectrophotometric system are more efficient in accurately determining the shade compared with the traditional visual assessment. Furthermore, measurements obtained from the VITA Easyshade spectrophotometers are repeatable and accurate up to nearly 2.5 years $[5,6]$. Nevertheless, there is a dearth of studies that have assessed the efficacy of this form of digital shade matching system. Based upon the currently available evidence, the ColorEye spectrophotometer also seems to be a useful digital resource for color matching of restorations with natural teeth [7]. However, there are no studies that have compared the efficacy of the VITA Easyshade and ColorEye spectrophotometers for color matching of ceramics before and after artificial accelerated aging (AAA). 
The objective of the present in-vitro study was to verify the efficacy of two spectrophotometer-based shade matching systems (VITA Easyshade and ColorEye) for color matching of ceramics after AAA. The null hypothesis is that there is no significant difference in the efficacy of the VITA Easyshade and ColorEye spectrophotometers for color matching of ceramics after AAA.

\section{MATERIAL AND METHODS}

\section{Sample-size estimation}

Sample-size estimation was performed using a computer-based power analysis software (nQuery Advisor 5.0, Statistical Solutions, Saugus, MA, USA). It was estimated that inclusion of 10 samples per group would give a $90 \%$ power to the study.

\section{Preparation of specimens}

Seventy disc-shaped specimens (thickness $\mathrm{x}$ diameter, $0.5 \mathrm{~mm} \times 10 \mathrm{~mm}$ ) of $\mathrm{B} 1$ shade were prepared according to the manufacturer's instructions from high translucency lithium disilicate blocks (Inoclar Vivadent AG, Schaan, Liechtenstein). The ceramic surfaces were finished and polished (LUSTER ${ }^{\circledR}$ LUS80 e.max ${ }^{\circledR}$, $\mathrm{Tx}$, USA) to assure surface standardization; and coated on one side with a layer of neutralshade glaze, and fired at $765{ }^{\circ} \mathrm{C}$ (Programat CS3 Ivoclar Vivadent, Schaan, Liechtenstein, Germany). Crystallization and sintering were done adhering to the manufacture's recommendations. Glazing and crystallization was done in one firing phase in accordance with the manufacture's recommendations.

\section{Grouping and cementation protocol}

In the present experimental study, the primary focus was on the efficacy of two spectrophotometer-based shade matching systems for evaluation of optical properties of ceramics after induction of aging using the Commission Internationale de l'Eclairage (CIE)
LAB system. Complete workflow from scanning to designing and the milling was done by using Ceramill CAD/CAM system (Amann Girrbach, Dürrenweg , Germany). Seven discs were milled from each block. Five discs (size C14) were obtained from each IPS e.max ${ }^{\circledR}$ CAD HT Blocks.

The samples were divided into 7 groups (10 specimens per group) according to the resin cement used (Table I). Prior to cementation, the porcelain surfaces were etched with $9 \%$ hydrofluoric acid (IPS Ceramic Etching Gel; (Ivoclar Vivadent, Schaan, Liechtenstein) for 20s and dried with oil-free compressed air. A layer of silane (prosil; FGM) was applied with a microbrush, left undisturbed for 1 minute, and air dried for 30 seconds. Ceramic primer (Mono bond S) for Variolink Esthetics dual cure, Variolink Esthetics light cure and Variolink Veneers; RelyX Ceramic Primer for RelyX Veneers, RelyX ultimate, RelyX unicem were applied for $5 \mathrm{~s}$ and dried. Bonding was performed using Adper Single Bond 2 Adhesive for the RelyX group. Light-cured resin cements were applied directly from a syringe. Dualcured resins were mixed on a separate mixing pad and applied onto the unglazed surface of the specimens, using a plastic instrument. Light-cured resin cements were applied directly from a syringe. Dual-cured resins were mixed on a separate mixing pad and applied onto the unglazed surface of the specimens using a plastic instrument; a clean glass slide was placed onto the resin mixture, and a $1-\mathrm{kg}$ weight was placed on top for 20 seconds to form a 0.1-mm-thick cement layer. In order to simulate clinical conditions, the top surfaces of all specimens were light-cured (Elipar S10; $3 \mathrm{M}$ ESPE) for 40 seconds. After cementation, irregularities from excessive resin cement were adjusted with 600-grit wet silicon-carbide paper (Norton Abrasives, MA, USA), and the specimen thicknesses were calibrated and standardized at $0.6 \mathrm{~mm}$ for all specimens. 


\section{Aging process}

After the cementation procedure, all specimens were placed in a silicone index; the glazed surfaces were in direct contact with water while the cemented sides were protected by the silicone index. All specimens were thermocycled (Thermocycler 1100 SD Mechatronik $\mathrm{GmbH}$, Germany) in water for 3,500 cycles between $5{ }^{\circ} \mathrm{C}$ and $55{ }^{\circ} \mathrm{C}$, with dwell times of 30 seconds in each bath and a transfer time of 10 seconds between baths.

\section{Color measurement}

The color difference $(\Delta \mathrm{E})$ was determined in the control group (only ceramic) using the equation: $\Delta \mathrm{E}=\left[\left(\Delta \mathrm{L}^{*}\right)^{2}+\left(\Delta \mathrm{a}^{*}\right)^{2}+\left(\Delta \mathrm{b}^{*}\right)^{2}\right]^{1 / 2}$. Color measurements were performed three times using two spectrophotometers, namely VITA Easyshade (Vita Zahnfabrik GmbH \& Co. KG, Bad Säckingen, Germany) and ColorEye (X-Rite Europe GmbH Regensdorf, Switzerland) using a viewing booth under D65 standard illumination on a white background, based on International Organization for Standardization (ISO) standards (ISO 7491; https://www.iso.org/standard/26857.html). A baseline color reading was performed 24 hours after cementation. The samples were stored in distilled water at $37^{\circ} \mathrm{C}$. After aging induction, the specimens were removed from the distilled water, dried with paper towels, and the $\mathrm{L}^{*} \mathrm{a} * \mathrm{~b} *$ coordinates were measured. Before the experimental measurements, the spectrophotometer was calibrated according to the manufacturer's instructions. The spectrophotometer was positioned in the middle of each specimen and each specimen was measured three times consecutively. The color measurements of the specimens were performed under the same conditions as used for the control group specimens, as described above, before and after aging. CIE L*a*b* notations were used for all color measurements. The CIE color difference was calculated before the cementation 'control group' with the equation:

$$
\Delta \mathrm{E}=\left[\left(\Delta \mathrm{L}^{*}\right)^{2}+\left(\Delta \mathrm{a}^{*}\right)^{2}+\left(\Delta \mathrm{b}^{*}\right)^{2}\right]^{1 / 2}
$$

where $L^{*}$ refers to the brightness, $a *$ for redness to greenness, and $b^{*}$ for yellowness to blueness. A high $\Delta \mathrm{E}$ value indicates great color difference. All assessments were done by a trained and calibrated investigator (FA; Kappa score 0.94).

\section{Statistical analysis}

The group comparisons were performed using a statistical software (SPSS version 20, Chicago, IL, USA). The means and standard deviations of the color changes were calculated. The paired t-test was used to analyze the differences between the groups. Level of significance was set at $\mathrm{P}<0.05$.

\section{RESULTS}

The mean differences in color $(\Delta \mathrm{E})$ values obtained from EasyShade spectrophotometer for light- and dual-cured cements, were $0.843 \pm 0.89$ (L-RV), 4.11 \pm 0.69 (L-VV) and $0.833 \pm 0.47 \quad(\mathrm{~L}-\mathrm{VE}) ; \quad$ and $2.22 \pm 0.64$ (DRU), $3.37 \pm 0.83$ (D-RC) and 0.38 \pm 0.92 (D$\mathrm{VE})$, respectively. The mean differences in color (DE) values obtained from ColorEye spectrophotometer for light- and dual-cured cements, were $0.68 \pm 0.86$ (L-RV), $4.55 \pm 0.83$ $(\mathrm{L}-\mathrm{VV})$ and $2.68 \pm 0.26(\mathrm{~L}-\mathrm{VE})$; and $2.06 \pm 0.84$ (D-RU), $1.8 \pm 1.08$ (D-RC) and 0.96 \pm 0.71 (DVE), respectively. There was no significant difference in the mean DE values among the groups (Table II). 
Table I - Allocation of specimens in the study groups

\begin{tabular}{|c|c|c|c|c|c|c|c|c|c|c|}
\hline \multicolumn{5}{|c|}{ Light cured cements } & \multicolumn{5}{|c|}{ Dual cured cements } & \multirow[b]{2}{*}{ COgroup } \\
\hline $\begin{array}{l}\text { Samples } \\
\text { (n) }\end{array}$ & $\begin{array}{c}\text { Material } \\
\text { used }\end{array}$ & Manufacturer & Composition & Lot & $\begin{array}{l}\text { Samples } \\
\text { (n) }\end{array}$ & $\begin{array}{c}\text { Material } \\
\text { used }\end{array}$ & Manufacturer & Composition & Lot & \\
\hline 10 & L-RV & $\begin{array}{l}\text { 3MESPE, Seefeld, } \\
\text { Germany }\end{array}$ & $\begin{array}{c}\text { BisGMA } \\
\text { TEGDMA } \\
\text { Zirconia/silica and } \\
\text { fumed silica } \\
\text { Pigments } \\
\text { Photoinitiator }\end{array}$ & N664127 & 10 & D-RU & $\begin{array}{l}\text { 3MESPE, Seefeld, } \\
\text { Germany }\end{array}$ & $\begin{array}{c}\text { Methacrylate } \\
\text { monomers } \\
\text { Aalkaline (basic) } \\
\text { fillers } \\
\text { Initiator } \\
\text { Stabilizers } \\
\text { Rheological ad- } \\
\text { ditives } \\
\text { Fluorescence dye } \\
\text { Dark cure activator } \\
\text { Universal adhesive }\end{array}$ & 583365 & \\
\hline 10 & L-VV & $\begin{array}{l}\text { Ivoclar Vivadent, } \\
\text { Schaan, Liech- } \\
\text { tenstein }\end{array}$ & $\begin{array}{l}\text { Dimethacrylates } \\
\text { Inorganic fillers } \\
\text { Ytterbium tri- } \\
\text { fluoride } \\
\text { Catalysts and } \\
\text { stabilizers } \\
\text { Pigments }\end{array}$ & T28526 & 10 & D-RC & $\begin{array}{l}\text { 3M ESPE, Seefeld, } \\
\text { Germany }\end{array}$ & $\begin{array}{l}\text { Powder: glass } \\
\text { fillers, silica, cal- } \\
\text { cium } \\
\text { hydroxide, self- } \\
\text {-curing initiators, } \\
\text { pigments, } \\
\text { light-curing ini- } \\
\text { tiators } \\
\text { Liquid:methacryla- } \\
\text { ted phosphoric } \\
\text { esters, } \\
\text { dimethacrylates, } \\
\text { acetate, stabilizers, } \\
\text { self-curing initia- } \\
\text { tors, } \\
\text { light-curing ini- } \\
\text { tiators }\end{array}$ & 590099 & $\begin{array}{l}\text { No cementation } \\
\quad(n=10)\end{array}$ \\
\hline 10 & L-VE & $\begin{array}{l}\text { Ivoclar Vivadent, } \\
\text { Schaan, Liech- } \\
\text { tenstein }\end{array}$ & $\begin{array}{l}\text { Urethane dime- } \\
\text { thacrylate Metha- } \\
\text { crylate monomers. } \\
\text { Ytterbium trifluori- } \\
\text { de and spheroid } \\
\text { mixed oxide. Initia- } \\
\text { tors, stabilizers and } \\
\text { pigments }\end{array}$ & T28801 & 10 & D-VE & $\begin{array}{l}\text { Ivoclar Vivadent, } \\
\text { Schaan, Liech- } \\
\text { tenstein }\end{array}$ & $\begin{array}{l}\text { Urethane dimetha- } \\
\text { crylate and further } \\
\text { methacrylate } \\
\text { monomers. } \\
\text { The inorganic } \\
\text { fillers are ytter- } \\
\text { bium trifluoride } \\
\text { and spheroid } \\
\text { mixed oxide. Initia- } \\
\text { tors, stabilizers and } \\
\text { pigments }\end{array}$ & T28801 & \\
\hline $\begin{array}{l}\text { CO: Contr } \\
\text { D-RU: Rely }\end{array}$ & $\begin{array}{l}\text { ol group } \\
\text { yX Ultimat }\end{array}$ & $\begin{array}{l}\mathrm{L}-\mathrm{RV} \\
\mathrm{D}-\mathrm{RC}\end{array}$ & $\begin{array}{l}\text { : RelyX Veneer } \\
\text { ऽ: RelyX Unicem }\end{array}$ & & $\begin{array}{l}\text { L-VV: Varic } \\
\text { D-VE: Vari }\end{array}$ & $\begin{array}{l}\text { ink Vene } \\
\text { link Estr }\end{array}$ & $\begin{array}{l}\text { eer } \\
\text { hetic }\end{array}$ & Variolink Estr & & \\
\hline
\end{tabular}

Table II - Mean and standard deviation of DeltaE $(\Delta \mathrm{E})$ measured by the two spectrophotometers and the results of paired t-test

\begin{tabular}{|c|c|c|c|c|}
\hline Cure type & Cement & $\Delta \mathrm{E}$ (Easyshade) & $\Delta \mathrm{E}$ (ColorEye) & p-value \\
\hline \multirow{3}{*}{ Light-cured } & L-RV & $0.843 \pm 0.89$ & $0.68 \pm 0.86$ & 0.293 \\
\hline & $L-W V$ & $4.11 \pm 0.69$ & $4.55 \pm 0.83$ & 0.820 \\
\hline & L-VE & $0.833 \pm 0.47$ & $2.68 \pm 0.26$ & 0.145 \\
\hline \multirow{3}{*}{ Dual-cured } & D-RU & $2.22 \pm 0.64$ & $2.06 \pm 0.84$ & 0.725 \\
\hline & D-RC & $3.37 \pm 0.83$ & $1.8 \pm 1.08$ & 0.246 \\
\hline & D-VE & $0.38 \pm 0.92$ & $0.96 \pm 0.71$ & 0.587 \\
\hline
\end{tabular}
L-RV: RelyX Veneer
L-VV: Variolink Veneer
L-VE: Variolink Esthetic
D-RU: RelyX Ultimate
D-RC: RelyX Unicem
D-VE: Variolink Esthetics 


\section{DISCUSSION}

An attractive esthetic smile is a principal goal in prosthetic and restorative dental sciences [8-10]. This is challenging because the human eye can detect and discern the subtlest color variations particularly in the aesthetic zone. There are numerous studies in indexed literature that have compared the efficacy of spectrophotomerty with visual analysis in terms of shade selection for porcelain-based dental prosthesis [11-14]. Results from such studies have clearly demonstrated that spectrophotometric assessment of shade for porcelain-based prosthesis is more reliable as compared to visual assessment [11-14]. For this reason, visual assessment of shade of the veneers was not performed in the current investigation.

Spectrophotometers are modern and accurate devices that gauge the quantity of light reflected from an object at 1-25 nm intervals along the visible spectrum. They are often used in clinical dentistry and related research for the purpose of color matching [15]. It ha also been reported that in contrast to visual assessment of shade, spectrophotometers are 33\% more accurate and offer a more objective match in over $93 \%$ cases [16]. There are few studies that have compared the efficacy of different spectrophotometers in terms of determining the precise shade for porcelain-based prosthetic veneers $[17,18]$. According to the results of the present in-vitro study, there was no difference in the efficacy of the two spectrophotometers used. One justification for this is that both spectrometric systems used in the present experiment are spot measurement devices that need to be brought into direct contact with the surface under investigation [17]. Moreover, both spectrophotometric analyses offer additional benefits based upon the CIE $\mathrm{L} * \mathrm{a} * \mathrm{~b} *$ systems for the detection of color changes that are not visible to the human eye [19]. Furthermore, strict standardization criteria were imposed in the present experiment. For instance, all specimens were standardized in terms of their dimensions (diameter $\mathrm{x}$ width $10 \times 0.5 \mathrm{~mm}$ ) and were polished prior to experimentation. Moreover, all specimens were thermocycled in water for 3,500 cycles between $5{ }^{\circ} \mathrm{C}$ and $55^{\circ} \mathrm{C}$, with dwell times of 30 seconds in each bath and a transfer time of 10 seconds between baths. Based upon such stringent yet standardized eligibility criteria comparable changes in on color between the two spectrophotometers assessed in the present study. In terms of use of light and dual-cure cements, it has been reported that Lithium disilicate ceramics are currently preferred for ceramic veneers and can be made thinner while masking the background [20]. Barizon et al. [20] reported that the biggest advantage of lithium disilicate porcelain is the possibility of fabricating thinner veneers without compromising strength and thereby allow considerably more translucent restorations. However, additional studies are needed to observe the influence of the type of cement on the final color of lithium disilicate ceramic.

To replicate a clinical scenario of aged restorations, the authors induced AAA in the samples. In the present study, 3,500 cycles was selected as it corresponds to the one-year clinical evaluation [21]. The concept of AAA has been imposed in several in-vitro investigations and has been recognized as a reliable technique to assess the color stability and fracture resistance of ceramics in experimentally aged restorations [22-27]. This may be considered a limitation of the present study as the outcomes were entirely based upon laboratory-based evaluations. It is also noteworthy that under clinical scenarios, extrinsic stains of varying intensity predominantly on aged veneers may influence the reliability of spectrophotometers. However, further studies are needed to justify this hypothesis.

\section{CONCLUSION}

Within the limitations of the present study, it is concluded that the VITA Easyshade and ColorEye shade matching systems are comparable in terms of their efficacy for color matching of ceramics after AAA. 


\section{Conflict of interest and financial disclosure}

The authors declare that they have no conflict of interest and there was no external source of funding for the present study.

\section{Acknowledgement}

None

\section{REFERENCES}

1. AlGhazali N, Burnside G, Smith RW, Preston AJ, Jarad FD. Performance assessment of Vita Easy Shade spectrophotometer on colour measurement of aesthetic dental materials. Eur J Prosthodont Restor Dent. 2011;19(4):16874.

2. Seghi RR, Johnston WM, O'Brien WJ. Performance assessment of colorimetric devices on dental porcelains. J Dent Res. 1989;68(12):1755-9.

3. Baltzer A, Kaufmann-Jinoian V. Shading of ceramic crowns using digital tooth shade matching devices. Int J Comput Dent. 2005;8(2):129-52.

4. Paul SJ, Peter A, Rodoni L, Pietrobon N. Conventional visual vs spectrophotometric shade taking for porcelain-fused-to-metal crowns: a clinical comparison. Int J Periodontics Restorative Dent. 2004;24(3):222-31.

5. Olms C, Setz JM. The repeatability of digital shade measurement--a clinical study. Clin Oral Investig. 2013;17(4):1161-6.

6. Fazi G, Vichi A, Corciolani G, Ferrari M. Spectrophotometric evaluation of color match to VITA classical shade guide of four different veneering porcelain systems for metal ceramic restorations. Am J Dent. 2009;22(1):1922

7. Shono NN, AI Nahedh HN. Contrast ratio and masking ability of three ceramic veneering materials. Oper Dent. 2012;37(4):406-16.

8. Mayekar SM. Shades of a color. Illusion or reality? Dent Clin North Am. 2001;45(1):155-72, vii.

9. Werling G. Veneers--treatment of Class V defects using the Cerec method. Int J Comput Dent. 2007;10(2):187-94.

10. Sadowsky SJ. An overview of treatment considerations for esthetic restorations: a review of the literature. J Prosthet Dent. 2006;96(6):433-42.

11. Perroni AP,Bergoli CD, Dos Santos MBF, Moraes RR, Boscato N. Spectrophotometric analysis of clinical factors related to the color of ceramic restorations: A pilot study.J Prosthet Dent. 2017;118(5):611-6.
12. Pimental W, Tiossi R. Comparison between visual and instrumental methods for natural tooth shade matching. Gen Dent. 2014;62(6):47-9.

13. Wang $P$, Wei J,Li $Q$, Wang Y.Evaluation of an optimized shade guide made from porcelain powder mixtures. J Prosthet Dent. 2014;112(6):1553-8.

14. Yilmaz B, Karaagaclioglu L. In vitro evaluation of color replication of metal ceramic specimens using visual and instrumental color determinations. J Prosthet Dent. 2011;105(1):21-7.

15. Chu SJ, Trushkowsky RD, Paravina RD. Dental color matching instruments and systems. Review of clinical and research aspects. J Dent. 2010;38 Suppl 2(e2-16.

16. Paul S, Peter A, Pietrobon N, Hämmerle CH. Visual and spectrophotometric shade analysis of human teeth. J Dent Res. 2002;81(8):578-82.

17. Dozić A, Kleverlaan CJ, El-Zohairy A, Feilzer AJ, Khashayar G. Performance of five commercially available tooth color-measuring devices. J Prosthodont. 2007;16(2):93-100.

18. Da Silva JD, Park SE, Weber HP, Ishikawa-Nagai S. Clinical performance of a newly developed spectrophotometric system on tooth color reproduction. $J$ Prosthet Dent. 2008;99(5):361-8.

19. O'Brien WJ, Hemmendinger H, Boenke KM, Linger JB, Groh CL. Color distribution of three regions of extracted human teeth. Dent Mater. 1997;13(3):179-85

20. Barizon KT, Bergeron C, Vargas MA, et al. Ceramic materials for porcelain veneers: part ll. Effect of material, shade, and thickness on translucency. J Prosthet Dent. 2014;112(4):864-70.

21. Manhart J, Scheibenbogen-Fuchsbrunner A, Chen HY,Hickel R. A 2-year clinical study of composite and ceramic inlays. Clin Oral Investig. 2000:4(4):192-198.

22. Karaokutan I, Yilmaz Savas T, AykentF, Ozdere E. Color Stability of CAD/ CAM Fabricated Inlays after Accelerated Artificial Aging. J Prosthodont. 2016;25(6):472-7.

23. Alqahtani Fl. Effect of newly Developed Resin Cements and Thermocycling on the Strength of Porcelain Laminate Veneers. J Contemp Dent Pract. 2017;18(3):209-13.

24. Barbon FJ, Moraes RR, Boscato N, Alessandretti R, Spazzin A0. Feldspar Ceramic Strength and The Reinforcing Effect by Adhesive Cementation Under Accelerated Aging. Braz Dent J. 2018;29(2):202-7.

25. Kvam K, Karlsson S. Solubility and strength of zirconia-based dental materials after artificial aging. J Prosthet Dent. 2013;110(4):281-7.

26. Pires-de-Souza Fde C, Casemiro LA, Garcia Lda F, Cruvinel DR. Color stability of dental ceramics submitted to artificial accelerated aging after repeated firings. J Prosthet Dent. 2009;101(1):13-8.

27. Kurt M, Turhan Bal B. Effects of accelerated artificial aging on the translucency and color stability of monolithic ceramics with different surface treatments. J Prosthet Dent. 2019;121(4):712.e711-2.e718.

\section{Dr. Fawaz Alqahtani}

(Corresponding address)

Department of Prosthodontics, College of Dentistry, Prince Sattam Bin Abdulaziz University, Al-Kharj 11942, Saudi-Arabia.

Email: implantologist@yahoo.com

Date submitted: 2020 Jun 22 Accept submission: 2020 0ct 06 